\title{
The Role of Internal Auditing in Controlling the Performance for Jordanian Industrial Companies: Empirical Evidence
}

\author{
Faris Soud Alqadi ${ }^{1}$ \\ ${ }^{1}$ Jerash University, Jordan \\ Correspondence: Faris Soud Alqadi, Jerash University, Jordan. E-mail: faris.1965@hotmail.com
}

Received: July 5, 2017

Accepted: August 2, 2017

Online Published: August 12, 2017

doi:10.5539/ijbm.v12n9p186

URL: https://doi.org/10.5539/ijbm.v12n9p186

\begin{abstract}
The aim of this study is to investigate the role of internal auditing in controlling the performance of Jordanian industrial companies. To achieve the study objective, the researcher distributed a questionnaire to (150) of the employees in the Jordanian industrial companies, (91) questionnaires were returned which was (60.67\%). In addition, the study attempted to verify the basic hypotheses and that of the study. On order to analyze the data, the researcher used the Mean, Standard Deviation, Percentages, and T-test. The result of the study revealed the presence of a very high degree relationship between the independence and objectivity of the internal auditor and his ability to control financial and administrative performance with (89.2\%), also there is a very high degree relationship between the adoption of clear criteria-tools for internal auditor and his ability to control the financial administrative performance with (75.76\%). Based on the result of hypotheses tested, the two null hypotheses of the study were rejected. In the light of the finding, the researcher gave a number of recommendations that are necessary to achieve the competitive advantages and quality assurance. The results of this study revealed that the internal audit function is one of the basic functions in Jordanian industrial companies and the internal auditor has the ability to discrimination indicator mistakes and distortions in the records and financial statements.
\end{abstract}

Keywords: internal audit, Jordanian industrial companies, internal auditors, audit committees, independence, and objectivity.

\section{Introduction}

The Hashemite Kingdom of Jordan is an important part of the world, due to its political stability, security, safety, high education, prestigious universities and technological progress in a various field. Accordingly, since companies have been rapidly increasing in number, growing in size, and developing in information technology (IT) in the corporate sector of the Jordan, they require better monitoring and control. Internal auditing, which is described as an aid for management (Jerome, 1953) can perform an invaluable service not only for the organization itself but also for society in general, if performed in a professional manner, thus. The purpose of this paper is to shed light on the role of internal auditing in controlling the financial and administrative performance of Jordanian industrial companies.

Business environment has witnessed rapid and revolutionary changes with broad impact to organizations throughout the world. As a result of this drastically development and changed, the internal auditing has become a vital element in the pivotal decisions that companies taking in regards to governance, information technology, new market and product opportunities, increasing regulation, changing workplace behaviour and the pace of organizational change is contributing to the increased velocity of emerging risk that can threaten business stability. In this regards, it has been argued that internal auditors have sufficient information and knowledge about companies which enable them to support companies' objectives (enabler of business performance). In addition, it can be said that they served as consultants when there is a necessity to effect the collective information gained during the audit to improve the companies (proactively support the board and management to enhancing standing business process) (Shahimi, et al., 2016)

Since of their knowledge of the nature and business environment, internal auditors tend to have sufficient knowledge to understand business characteristics. In other words, the internal audit functions helps companies accomplish and achieve their objectives through a systematic disciplined approach to evaluate and advance the effectiveness of risk management. (IPPF, 2013, p. 2). Global Internal Auditing survey of the Institute of Internal Auditors (IIA) 2010, indicates that as a result of the new challenges of current business environment faced by 
companies the maximizing the Internal Audit Functions has become imperative in order to drive positive impact, change and improvement. (IIARF,2010\& b, IIARF,2011, a,b,c\&d)

\subsection{Main Study Question}

This study attempts to answer the following question:

Is there a role for the internal auditing units in controlling the financial and administrative performance of Jordanian industrial companies?

\subsection{Objective of the Study}

This paper attempts to address a largely ignored topic of the role of internal auditing in controlling the performance of Jordanian industrial companies, specifically, this study examined:

a) The relationship between independence, the objectivity of internal audit and its ability to control financial and administrative performance in Jordanian industrial companies.

b) The relationship between the adoption of clear performance criteria for internal auditing and the control of financial and administrative performance in Jordanian industrial companies.

\subsection{Hypotheses of the Study}

Ho1: There is no statistically significant relationship between the independence and objectivity of internal auditing and its ability to control financial and administrative performance in Jordanian industrial companies.

Ho2: There is no statistically significant relationship between the adoption of clear performance criteria for internal auditing and the control of financial and administrative performance in Jordanian companies.

\section{Literature Review}

Since no study was found focusing particularly on a performance of internal auditing in the Jordan, this literature review will cover the studies that discussed or related to a performance of internal auditing.

Standards of professional practice of internal auditing (SPPIA) emphasized that "audit work should include planning the audit, examining and evaluating information, communicating results, and following up.

SEPIA saw planning the audit work to be the first step to being embraced by internal auditors and so in the performance of audit work standard, planning was the first of its specific sub-standards. II-UK (1988) reported that external auditors mentioned "quality control of audit work, planning, supervising and review of work" as important criteria to be considered when evaluating the internal audit function. One important aspect of the planning process is the preliminary survey that as noted by Robertson (1993), helps familiarization with the activity being audited and helps identify problem areas. Familiarization with the audited activity and problem area identification are the reasons why internal auditors commonly begin the audit engagements with a preliminary survey (Brody\& Kaplan, 1996).

In their study, Wood and Wilson (1989) tested the impact of stress on performance of audit work, from the responses to a questionnaire survey of 518 (response rate 28\%) of the UK and Canadian members of the IIA, the authors conclude that internal auditors who perform as well as other not experiencing such stress. The researcher noticed that measuring the performance of internal audit function is a quite complex and difficult task for practical implementation. Wynne (1999) emphasize that planning is an essential part of current internal auditing, and in order to do it successfully, Wynne suggests taking the following three objectives into account when doing the audit planning process assurance, risk management, and external audit reliability.

Selim and Mc Namee (2001) studied the involvement of internal auditing in risk management when performing the audit work. The noted, "if the auditor focuses on risks, the audit is more likely to address the full range of issues that concern management" (p. 162) they also suggested that internal auditors should identify and focus on risk instead of testing controls.

Selim et al. (2009) conducted a comparative study of factors affected internal audit consulting activities carried out by a sample of The Institute of Internal Auditors members in the UK/Ireland and Italy. The results of study show that a noteworthy growth in consulting activities carried out in Italian companies, and internal auditors are experiencing both benefits and drawbacks in both countries. Furthermore, he stated that the consulting part of internal auditors is voluntary rather than mandatory for them to create value added for the benefits of the company to which they are committed.

In attempt to study and investigate the organizational and drivers of internal audit effectiveness, Arena and Azzon (2009) surveyed 153 Italian companies. Their study revealed that there are many issues and factors 
influenced internal audit effectiveness such as the characteristics of the internal audit team, the Audit process and activities and the organizational link.

In the same vine, Anderson et al. (2012) investigated the internal audit function. They stated that the internal audit function is influenced by many factors audit committee governance, experience of the chief audit executive, the use of audit technologies, organization size. Moreover, the percentage of internal audit stuff that are certificated internal auditor and the extent of assurance and compliance activities outsourced to an outsider play a vital role in the process of decreases the amount of work performed by the internal auditors and is an indicator of performance.

Dellai and Omri (2016) investigated the factors influencing internal audit effectiveness in the Tunisian context through surveyed 148 Tunisian organizations. Their study showed that the most factors affected the effectiveness of internal auditing are; independency and objectivity of internal auditor, management supporting, organizational sector, and the use of internal audit function as a management training ground. In attempt to examine the role of internal audit in performance of Libyan financial organizations.

Alaswad and Stanišić (2016) investigated financial reports of 26 financial companies listed in Libya Stock Market. They revealed that internal audit committee size have their own impact on performance, whereas the audit committee independence, the auditor's qualification and the auditor's experience affected the performance.

Amoush (2017) examined the effectiveness of the internal auditing procedures in the Jordanian commercial banks. The study indicates that internal auditing procedures and the role of the board of directors have a great impact on ensuring the effectiveness of the internal auditing. Additionally, internal auditing program and procedures ensure the internal auditor's independence.

\section{Research Methodology}

This study reports the results of a survey of accountants industry regarding the role of internal audit in controlling the performance of industrial companies listed on Amman Stock Exchange. The questionnaire elicited demographic information about the respondents. Specifically, this study examines:

a- The relationship between the independence and objectivity of the internal auditing and its ability to control the internal financial and administrative performance in Jordanian industrial companies.

b- The relationships between the adoption of clear performance criteria for internal auditing and the control of financial and administrative performance in Jordanian industrial companies.

The questionnaire was distributed to a random sample of (150) accountants working in industrial companies in April 2017. These accountants were chosen at random from a listing of certified public accountants working in the Hashemite Kingdom of Jordan. There were 91 response received giving a response rate of $60.67 \%$

\subsection{Study Tool}

after reviewing previous staying and the literate of accounting that regarding internal auditing the researcher develop a questionnaire which included (26) items relating to internal auditing and its ability to controlling the financial and administrative performance in Jordanian industrial companies.

\subsection{Statistical Test}

Statistical methods applied to analyze data are means, standard deviation, and percentages.

\subsection{Scale}

Likert scale was adopted which consists of five degrees to determine how much the responders agree or disagree with each item in the questionnaire as for how in the Table 1.

Table 1. Likert scale

\begin{tabular}{ll}
\hline Scale & degree \\
\hline Strongly disagree & 1 \\
Disagree & 2 \\
Neutral & 3 \\
Agree & 4 \\
Strongly degree & 5 \\
\hline
\end{tabular}


To interpret Likert scale results, weighted mean to represent each question was computed. Table (2) shows the level of agreement associated with each weighted average mean range.

Table 2. weighted mean level of agreement

\begin{tabular}{ll}
\hline weighted mean & the level of agreement \\
\hline More than $4.2-5$ & Very high \\
More than $3.4-\mathbf{4 . 2}$ & High \\
More than $2.6-3.4$ & Average \\
More than $1.8-\mathbf{2 . 6}$ & Average \\
$\mathbf{1 . 8}$ and less & Very week \\
\hline
\end{tabular}

\subsection{Result}

Table 3. Presents descriptive information regarding demographic characteristics of the study sample

\begin{tabular}{|c|c|c|c|c|}
\hline Variables & Class & Frequency & percentage & Accumulative percentage \\
\hline \multirow[t]{4}{*}{ Age } & Less than 30 & 27 & $29.67 \%$ & 29.67 \\
\hline & $30-40$ years & 42 & $46.15 \%$ & 75.82 \\
\hline & More than 40 & 22 & $24.18 \%$ & 100 \\
\hline & Total & 91 & $100 \%$ & \\
\hline \multirow[t]{4}{*}{ Experience } & Less than 5 years & 24 & $26.37 \%$ & 26.37 \\
\hline & $5-10$ years & 44 & $48.35 \%$ & 74.72 \\
\hline & More than 10 years & 23 & $25.28 \%$ & 100 \\
\hline & Total & 91 & $100 \%$ & \\
\hline \multirow[t]{4}{*}{ Qualification } & Diploma & 9 & $9.89 \%$ & 9.89 \\
\hline & Bachelor & 67 & $73.63 \%$ & 83.52 \\
\hline & Master & 15 & $19.48 \%$ & 100 \\
\hline & Total & 91 & $100 \%$ & \\
\hline \multirow[t]{5}{*}{ Specialization } & Accounting & 73 & $80.22 \%$ & 80.22 \\
\hline & Business administration & 87 & $7.69 \%$ & 87.91 \\
\hline & Finance & 9 & $9.89 \%$ & 97.80 \\
\hline & Economics & 02 & $2.20 \%$ & 100 \\
\hline & Total & 91 & $100 \%$ & \\
\hline Profession & Normal internal auditor & 32 & $36 \%$ & 35.60 \\
\hline \multirow[t]{4}{*}{ Career or position } & Director of auditing unit & 10 & $11 \%$ & 46.70 \\
\hline & Major auditor & 20 & $22 \%$ & 68.90 \\
\hline & Assistant auditor & 28 & $31 \%$ & 100 \\
\hline & Total & 90 & 100.0 & \\
\hline \multirow[t]{6}{*}{ Certificates } & CPA & 6 & $7 \%$ & 6.66 \\
\hline & $\mathrm{ACPA}$ & 10 & $11 \%$ & 17.78 \\
\hline & JCPA & 32 & $36 \%$ & 53.33 \\
\hline & CIA & 15 & $17 \%$ & 70.00 \\
\hline & without & 27 & $30 \%$ & 100 \\
\hline & Total & 90 & 100.0 & \\
\hline
\end{tabular}

Table 3 shows that the majority of those who completed the questionnaire were over 30 years of age, where their percentage (70.33). In contrast who they under 30 years of age their proportion (29.67). The researchers see this as the good indicator that will have a positive effect on respondents of sample pf the study. The table also shows that the largest proportion of the study sample increases their experience for five years where their percentage (73.63). Table 1 shows that (90.11) of the study sample is from the bachelor and master degrees, while those with less than first university degree of $(9.890$, the researcher believes that this result reflects the importance of qualification in Jordanian industrial companies. Moreover, the largest proportion of respondents are from the certified auditors major and the proportion is $70 \%$, and this gives a further indication that these respondents 
attain scientific and practical experience regarding the subject of internal auditing and its impact on the field of their professional leadership, this fits adequately with their professional certificate which they hold where was the largest percentage of them are carrying CPA, ACPA, JCPA and CIA, proportion was $7 \%, 11 \%, 36 \%$ and $17 \%$ respectively, as well as it shows that the major respondents are among the assistance auditors and the normal internal auditors and the proportion was $31 \%$ and $36 \%$ correspondingly. This also indicates that they are skillful and expert in their profession in addressing the financial and accounting issues regarding internal auditing among them.

Finally, Table 3 shows that (80.22) of the study sample are accounting specialist while the other disciplines such as business administration (7.89), Finance (0.89) and economy (2.2), So the researcher believes that this result will have a qualitative impact of the answers provided by the sample of the study because this category has an accounting information base commensurate with the subject of the study.

Table 4. Test the relationship between the independence and objectivity of the internal auditor and his ability to control financial and administrative performance

\begin{tabular}{|c|c|c|c|c|c|}
\hline Number & Items & $\begin{array}{l}\text { Mean } \\
\text { averages }\end{array}$ & $\begin{array}{l}\text { standard } \\
\text { deviation }\end{array}$ & percentage & $\begin{array}{l}\text { Degree of } \\
\text { importance }\end{array}$ \\
\hline 1 & $\begin{array}{l}\text { The Internal Audit Manager has a direct line of communication } \\
\text { with the Board of Directors or the Audit Committee }\end{array}$ & 4.82 & 0.42 & $96.2 \%$ & Very high \\
\hline 2 & $\begin{array}{l}\text { The internal auditor maintains his independence through his } \\
\text { independence on the activities he reviews }\end{array}$ & 4.70 & 0.52 & $94 \%$ & Very high \\
\hline 3 & $\begin{array}{l}\text { The internal auditor performs executive functions assigned to } \\
\text { him by the senior management and then checks the operations, } \\
\text { including what he has done }\end{array}$ & 4.67 & 0.89 & $93.4 \%$ & Very high \\
\hline 4 & $\begin{array}{l}\text { The internal auditor is able to make his decision without pressure } \\
\text { or obedience to those whose decisions influence them }\end{array}$ & 4.63 & 0.56 & $92.6 \%$ & Very high \\
\hline 5 & $\begin{array}{l}\text { The head of internal audit is appointed and appointed with the } \\
\text { approval of the Board of Directors or the Audit Committee }\end{array}$ & 4.57 & 0.86 & $91.4 \%$ & Very high \\
\hline 6 & $\begin{array}{l}\text { The internal auditor balances with great caution between being } \\
\text { an employee within the bank and maintaining his independence } \\
\text { and impartiality in performing his professional duties }\end{array}$ & 4.52 & 0.78 & $90 \%$ & Very high \\
\hline 7 & $\begin{array}{l}\text { It is very important to have a direct contact line of the internal } \\
\text { auditor with the Audit Committee in order to strengthen its } \\
\text { independence }\end{array}$ & 4.47 & 0.82 & $89.4 \%$ & Very high \\
\hline 8 & $\begin{array}{l}\text { The internal auditor can deliver his opinion without hindrance to } \\
\text { the Audit Committee or the Board of Directors when he } \\
\text { discovers errors or risks that affect the objectives }\end{array}$ & 4.32 & 0.68 & $86.4 \%$ & Very high \\
\hline 9 & $\begin{array}{l}\text { The internal auditor is able to show the highest degree of } \\
\text { objectivity in his work and is not subject to the influence of his } \\
\text { personal interests }\end{array}$ & 4.30 & 0.71 & $86 \%$ & Very high \\
\hline 10 & $\begin{array}{l}\text { The independence of the internal auditor depends heavily on the } \\
\text { location of the audit department in the organizational structure } \\
\text { and its non-follow-up of administrative departments and } \\
\text { departments }\end{array}$ & 4.28 & 0.62 & $85.6 \%$ & Very high \\
\hline 11 & $\begin{array}{l}\text { Independent Audit Committees are established by understanding } \\
\text { the tasks assigned to them }\end{array}$ & 4.24 & 0.78 & $84.8 \%$ & Very high \\
\hline 12 & $\begin{array}{l}\text { The work environment ensures that the internal auditor is } \\
\text { committed to honesty, objectivity, diligence, and diligence in the } \\
\text { performance of his duties and responsibilities }\end{array}$ & 4.21 & 0.95 & $84.2 \%$ & Very high \\
\hline \multirow[t]{2}{*}{13} & $\begin{array}{l}\text { There is an intervention by individuals outside the internal audit } \\
\text { department in their internal audit work }\end{array}$ & 4.19 & 0.63 & $83.8 \%$ & Very high \\
\hline & Total & 4.46 & 0.71 & $89.2 \%$ & Very high \\
\hline
\end{tabular}

Table 4 shows that the responses of the study sample on the test of the relationship between the independence and objectivity of internal auditor and his ability to control financial and administrative performance. Table (4) 
shows that there is a very high correlation between the independence and objectivity of internal auditors and his ability to control financial and administrative performance. It is noted from the table 4 that the means for all the paragraphs appearing in the table 4 ranged from (4.82-4.16) while the standard deviation ranging from (0.42-0.95) and percentage from (83.8\%-96.2\%). With regard to the total score, the mean was (4.46), while the standard deviation was (0.71), percentage (89.2) and the degree of importance "very high". The researcher sees that the deviation of the total score 0.71 indicates a relative homogeneity in the opinion of the study sample on the importance of all paragraphs.

Table 5. Test the relationship between the adoptions of clear criteria-tools for internal auditor and his ability to control the financial and administrative performance

\begin{tabular}{|c|c|c|c|c|c|}
\hline No & items & $\begin{array}{l}\text { mean } \\
\text { averages }\end{array}$ & $\begin{array}{l}\text { standard } \\
\text { deviation }\end{array}$ & percentage & $\begin{array}{l}\text { Degree } \\
\text { importance }\end{array}$ \\
\hline 1 & $\begin{array}{l}\text { The internal audit function is one of the core functions of Jordanian } \\
\text { industrial }\end{array}$ & 4.70 & 0.81 & $94 \%$ & Very high \\
\hline 2 & $\begin{array}{l}\text { The internal audit function of Jordanian industrial companies has } \\
\text { sufficient financial and human resources }\end{array}$ & 4.43 & 0.50 & $88.6 \%$ & Very high \\
\hline 3 & $\begin{array}{l}\text { Internal auditors have sufficient knowledge of internal audit standards } \\
\text { issued by the Institute of Internal Auditors }\end{array}$ & 4.42 & 0.53 & $88.4 \%$ & Very high \\
\hline 4 & $\begin{array}{l}\text { The purpose, responsibilities, and scope of internal audit management } \\
\text { are clear, well defined and specific }\end{array}$ & 4.40 & 0.53 & $88 \%$ & Very high \\
\hline 5 & $\begin{array}{l}\text { Internal auditing can provide information in a precise and orderly } \\
\text { manner for the senior management to make its decision and assist in } \\
\text { the examination, evaluation, and safety of procedures }\end{array}$ & 4.32 & 0.46 & $86.4 \%$ & Very high \\
\hline 6 & $\begin{array}{l}\text { An internal audit function examines compliance with internal } \\
\text { financial and administrative policies and orders, as well as } \\
\text { compliance with Jordanian laws and regulations }\end{array}$ & 4.30 & 0.66 & $86 \%$ & Very high \\
\hline 7 & $\begin{array}{l}\text { The internal auditor has the ability to distinguish risk indicators and } \\
\text { distortions in records and financial statements }\end{array}$ & 4.29 & 0.92 & $85.4 \%$ & Very high \\
\hline 8 & The internal auditor is responsible for detecting material errors & 4.27 & 0.61 & $85.4 \%$ & Very high \\
\hline 9 & $\begin{array}{l}\text { The internal auditor is responsible for the detection of non-material } \\
\text { errors }\end{array}$ & 4.20 & 0.48 & $84 \%$ & Very high \\
\hline 10 & $\begin{array}{l}\text { The industrial companies management provides training courses for } \\
\text { internal auditors to inform them of recent developments in the field of } \\
\text { the profession }\end{array}$ & 4.18 & 0.56 & $83.6 \%$ & Very high \\
\hline 11 & $\begin{array}{l}\text { The tasks assigned to the internal audit require a shift from a routine } \\
\text { financial audit to an audit of the operations and the activities of the } \\
\text { industrial companies }\end{array}$ & 4.13 & 0.76 & $82.6 \%$ & Very high \\
\hline 12 & $\begin{array}{l}\text { Internal audit reports are the most important means for senior } \\
\text { management }\end{array}$ & 4.1 & 0.88 & $82 \%$ & Very high \\
\hline \multirow[t]{2}{*}{13} & $\begin{array}{l}\text { The performance standards for internal audit require the internal } \\
\text { auditor to have the appropriate professional skill and to determine the } \\
\text { scope of work }\end{array}$ & 4.00 & 0.62 & $80 \%$ & Very high \\
\hline & Total & 4.288 & 0.64 & $85.76 \%$ & Very high \\
\hline
\end{tabular}

Table 5, shows that the mean of test the relationship between the adoptions of clear criteria-tools for internal auditor and his ability to control the financial and administrative performance ranged between (4.70-4), the highest three means were for test relationship between the adoptions of clear criteria-tools for internal auditor and his ability to control the financial and administrative number (1),(2), (3) and the lowest three means for test the relationship between the adoptions of clear criteria-tools for internal auditor and his ability to control the financial and administrative number (13), (12), (11).In addition, Table 3 shows that the significance was very high for all paragraphs.

Total degree: means was (4.88), the standard deviation was $(0.64)$, percentage $(85.76 \%)$ and importance degree very high. These results indicate that there is no much variation in the study sample response. 


\subsection{Hypotheses Testing}

To ascertain the validity of the finding, the researcher conducted a t-test

Ho1: There is no statistically significant relationship between the independence and objectivity of internal auditing and its ability to control financial and administrative performance in Jordanian industrial companies.

Table 6. T-test

\begin{tabular}{llllll}
\hline Hypothesis & T-value & T-table & Sig (T) & $\boldsymbol{\alpha}$ & result \\
\hline HO1 & 2.216 & 1.645 & 0.030 & 0.050 & Rejected \\
\hline
\end{tabular}

Sig $(t)=0.030<0.050$ as result, the null hypothesis is rejected alternative one is accepted

Ho2: There is no statistically significant relationship between the adoption of clear performance criteria for internal auditing and the control of financial and administrative performance in Jordanian companies.

Table 7. T-test

\begin{tabular}{llllll}
\hline Hypothesis & T-value & T-table & Sig (T) & $\boldsymbol{\alpha}$ & result \\
\hline HO2 & 2.030 & 1.645 & 0.041 & 0.050 & Rejected \\
\hline
\end{tabular}

Sig $(\mathrm{t})=0.041<0.050$ as result, the null hypothesis is rejected alternative one is accepted

\section{Conclusion}

Based on the statistical analysis and hypotheses testing performed the researcher was able to conclude that there is a higher role of internal audit in controlling the performance of Jordanian industrial companies. There is a very high relationship between the independence objectivity of the internal auditor and his ability to control financial and administrative performance. Also, there is a very high relationship between the adoptions of clear criteria-tools for internal auditor and his ability to control the financial and administrative performance Furthermore, the internal audit function is one of the basic functions in Jordanian industrial companies and the internal auditor has the ability to discrimination indicator mistakes and distortions in the records and financial statements, The purpose, responsibilities, and scope of internal audit management are clear, well defined and specified in the Jordanian industrial companies. The researcher recommended to the need for a hotline of communication for the internal auditor with the Audit Committee, and to limit the interference of individuals outside the internal audit unit in the internal audit work in the Jordanian industrial companies

This result consists of some findings of following studies: Robertson (1993); Selim and Mc Namee (2001); Wynne (1999).

\section{References}

(The) Institute of Internal Auditors Research Foundation (IIARF). (2010a). Global Summary of the common body of knowledge study 2010, characteristics of an internal audit activity (Report 1) Altamonte Springs, Florida: IIA Research Foundation.

(The) Institute of Internal Auditors Research Foundation (IIARF). (2010b). Global Summary of the common body of knowledge study 2010, Core competencies for today's internal auditor (Report II) Altamonte Springs, Florida: IIA Research Foundation.

(The) Institute of Internal Auditors Research Foundation (IIARF). (2010c). Global Summary of the common body of knowledge study 2010, Measuring internal auditing value (Report III). Altamonte Springs, Florida: IIA Research Foundation.

(The) Institute of Internal Auditors Research Foundation (IIARF). (2010d). Global Summary of the common body of knowledge study 2010, What's next for internal auditing? (Report IV). Altamonte Springs, Florida: IIA Research Foundation.

(The) Institute of Internal Auditors Research Foundation (IIARF). (2011a). Global Summary of the common body of knowledge study 2010, A call to action: Stakeholders Perspective on Internal Auditing: Altamonte Springs, Florida: IIA Research Foundation. 
(The) Institute of Internal Auditors Research Foundation (IIARF). (2011b). Global Summary of the common body of knowledge study 2010, Imperatives for change (Report V). Altamonte Springs, Florida: IIA Research Foundation.

Alaswad, S. A. M., \& Stanišić, M. (2016). Role of internal audit in performance of Libyan financial organizations. International Journal of Applied Research, 2(2), 352-356.

Amoush, A. H. (2017). The Internal Auditing Procedures Effectiveness in the Jordanian Commercial Banks. International Business Research, 10(3).

Anderson, V. (2003). In Assurance and Consulting \& S. Ramaoorti (Eds.), Research opportunities in internal auditing (pp. 97-129). Altamonte Spring Florida: The Institute of Internal Auditors Research Foundation.

Arena, M., and, Azzone, G. (2009). Identifying organizational Drivers of Internal Audit Effectiveness. International Journal of Auditing 13(1), 43-60. http://dx.doi.org/10.1111/i.1099-1123.2008.00392.x

Brody, R. and S. Kaplan (1996) Escalation of commitment among internal auditors. A Journal of Practice \&Theory, 15(1), 1-15.

Chen, R. S. (1975). Social and Financial stewardship. The Accounting Review, 50(3), 533-543.

Chia, A. (2004). Internal auditors' partners in boosting corporate governance. Business Times, 6.

Dellai, H., \& Omri, M. A. B. (2016). Factors Affecting the Internal Audit Effectiveness in Tunisian Organizations. Research Journal of Finance and Accounting, 16(16).

Gjesdal, F. (1981). Accounting for stewardship. Journal of Accounting Research, 19(1), 208-231. http://dx.dol.og/10.237/2490970

International Professional Practices Framework (IPPF). (2013). Altamonte Springs, Florida: The Institute of Internal Auditors Research Foundation. Retrieved from http://na.theiia.org/Standards-guidance/pages/standards-andGuidance-IPPF.aspx

Jerome, W. T. (1953). Internal auditing as an aid to management. Harvard Business Review, 127-136.

O'sullivan, N. (2000). The Impact of board composition and ownership on auditing quality: Evidence from large UK companies. The British Accounting Review, 32(4), 397-414. http://dx.doi.org/10.1006/bare.2000.0139

Robertson, J. (1993). Auditing (7th ed.). Homewood, IL, Irwin.

Rosen, F. (1974). Stewardship. In J. D. Gramer \& G. H. Sorter (Eds.), objectives of financial statement Vol.2-Selected papers (pp. 123-140). New York: American Institute of Certified Public Accountants.

Selim, G, Wood Word, S., \& Allegrini, M. (2009). Internal Auditing and consulting practice: A comparison between UK/Ireland and Italy. International Journal of Auditing 13(1), 9-25. http://dx.doi.org/10.1111/j.1099-1123.2008.00395

Selim, G., \& Mc Namee, D. (2001). Risk management the reinvention of internal control and the changing role of internal and its Accounting. Auditing and Accountability Journal, 16(4), 640-661.

Shahimi, S., Mahzan, N. D., \& Zulkifli, N. (2016). Value Added Services of Internal Auditors: An Exploratory Study on Consulting Role in Malaysian Environment. International Journal of Management Excellence, 7(1). https://doi.org/10.17722/ijme.v7i1.220

Wood, D. J., \& Wilson, J. A. (1989). Roles and Relationships in Internal Auditing. Behavioral Auditing Series, (2). The Institute of Internal Auditors Research Foundation, USA.

Wynne, A. (1999). Planning Priorities. Internal Auditing, 22-23.

\section{Copyrights}

Copyright for this article is retained by the author(s), with first publication rights granted to the journal.

This is an open-access article distributed under the terms and conditions of the Creative Commons Attribution license (http://creativecommons.org/licenses/by/4.0/). 